\title{
BORGES'S POE. THE INFLUENCE AND REINVENTION OF EDGAR ALLAN POE IN SPANISH AMERICA. EMRON ESPLIN
}

Athens: University of Georgia Press, 2018. pp. 238. ISBN 9780820349053

\author{
SANTIAGO RODRÍGUEZ GUERRERO-STRACHAN \\ Universidad de Valladolid \\ guerreroyl.uva.es
}

Received 25 July 2018

Accepted 27 September 2018

A cursory glance at Borges's essays shows an impressive range of authors, most of whom came from outside of literature in Spanish. Borges always expressed his admiration for English and American authors, among them S.T. Coleridge, William Shakespeare or Robert Louis Stevenson. In the essay "El escritor argentino y la tradición," published in Discusion in 1932 (1957), he discusses the notion of national literature and the extent to which it may be used in a literature such as the Argentinean, which does not date back to the ninth century, as is the case of English literature. Borges thought that Argentinean writers were much freer than Europeans due to this lack of literary tradition and that they could find precursors not only in Argentinean writing but in world literature. Thus it makes sense that he appreciated authors from around the world and attached a value to their works that surpassed literary appreciation.

Emron Esplin explores in Borges's Poe the ways in which Borges created the figure of Poe as a short-story writer via literary criticism, translations and creation. Esplin has coedited the magnificently comprehensive collection of essays on the translations of Poe from around the world Translated Poe (2014). He himself has written some essays on Borges and Poe and Borges and Hawthorne while writing extensively on the topic of the reception of Poe in America. Esplin's research focuses on the inter-American dialogue of cultures by analyzing the material reception such as the anthologizing of Poe's writings.

In Borges's Poe Esplin analyzes three aspects of Poe's work. First he explores the way in which Borges changed the 
idea that South American readers had of Poe, who was already known to the readership thanks to Rubén Dario's essay in Los raros. For this modernista author, Poe was a genius and a poetprophet in a romantic vein, whose work was poetical for the most part. Borges challenged Dario's appreciation of Poe and managed to change the figure of the poet-prophet to that of the writer of short fiction. For that purpose he wrote some influential essays among which stand "La genesis de 'El cuervo' de Poe" (1935), "El cuento policial" [1978] (2017) and his prologues to Poe's anthologies (1985, [1986] 2007). Borges discusses "The Philosophy of Composition" to finally conclude that Poe did not tell the truth about "The Raven" and preferred to emphasize a method that was highly raciotinative and which excludes any hint of magic and, therefore, rules any possibility of being a poet-prophet.

The second step in the creation of Poe as a short-story writer was the translation of Poe's works, a task that Esplin discusses in great detail in the second part of the book. He uses John Holmes's theory of translation and Itamar EvenZohar's theory of the polysystems. By translating Poe Borges would domesticate him and would find him a place in Argentinean literature. Esplin discusses Borges's essays on translation, to conclude that Borges thought of translation as a part of literary creation, and then examines "the Facts in the Case of M. Valdemar" and "The Purloined Letter" that Borges translated with Adolfo Bioy Casares, and the fragments of The Narrative of Arthur Gordon Pym of Nantucket that Borges also translated. Not uncoincidentally Borges prefers a style that resembles his own and that is close to Charles Baudelaire's translations of Poe. While Poe used a highly wrought style, both Borges and Baudelaire preferred to make it plainer in their translations. By domesticating Poe, Borges streamlined Poe's source text and added emphasis to some of the arguments. These translations were also instrumental in challenging Modernismo and favoring Borges's poetics.

Finally Esplin compares Poe's and Borges's fiction. He acknowledges that most scholars, notably John Irwin, have studied the detective fiction of both writers. Esplin manages to convey new insights in the comparison by reading "Loss of Breath" against "Funes el memorioso" and "El Aleph." What is remarkable is Esplin's conclusion that Borges not only knew "Loss of Breath" and used it as a hypotext for his fiction but that Borges's stories create a new Poe. He had already explored the topic precursors in "Kafka y sus precursores" ([1951] 2007). Esplin also deals with Borges's theory on the fantastic, a notion 
about which, though the writer wrote about it extensively, he never reached a satisfactory conclusion, as Esplin demonstrates. This was no obstacle to his writing some of the most fascinating fantastic stories of the twentieth century. Esplin's reading of "Metzengerstein" and "The Black Cat" alongside "El Aleph" focuses on the plot of revenge that the three stories share and is put at the forefront by the reading of the fiction of the Argentinean.

Esplin convincingly argues for Borges's refashioning of Poe from poet-prophet to fiction writer in ways that sometimes may seem intricate. It is his accomplishment to show these ways that scholarship had written off until now, and to show the inter-American literary connections. Besides, the epilogue, focused on Julio Cortázar's translations and essays on Poe, no doubt encouraged by Borges's interest in Poe, hints towards new explorations of Poe's life in America. It was not only Cortázar who was fascinated by Poe in the 1950s. Ramón Goméz de la Serna, a Spanish writer by then exiled in Argentina, also published a biography of Poe in 1953. To him the writings of Felisberto Hernández and Santiago Dabove, two writers from the Rio de la Plata region, should be added. A more detailed exploration of their fantastic stories and the process of composition of their works may shed new light on Poe's afterlife in America.

\section{WORKS CITED}

BORGES, Jorge Luis. "El escritor argentino y la tradición." Discusión. Emecé, 1957, pp. 151-162.

---. "La genesis de 'El cuervo' de Poe.” La Prensa. 25 Aug. 1935, sec. 4th.

---. "El cuento policial." Obras completas. Vol.4, Emecé, 2007, pp. 229-240.

---. "Prólogo a Edgar Allan Poe, La carta robada." La carta robada. Siruela, 1985, pp. 9-13.

---. "Prólogo a Edgar Allan Poe, Cuentos." Obras completas. Vol. 4. Emecé, 2007, pp. 646-647.

---. "Kafka y sus precursores.” Obras completas. Vol. 2. Emecé, 2007, pp. 107-109.

ESPLIN, Emron, and Margarida Vale do Gato, editors. Translated Poe. Lehigh University Press, 2014. 